IZA DP No. 10377

Small-Scale Farming and Food Security:

The Enabling Role of Cash Transfers in

South Africa's Former Homelands

Dieter von Fintel

Louw Pienaar

November 2016 


\title{
Small-Scale Farming and Food Security: The Enabling Role of Cash Transfers in South Africa's Former Homelands
}

\author{
Dieter von Fintel \\ Stellenbosch University, ReSEP, LEAP \\ and IZA \\ Louw Pienaar \\ Western Cape Department of Agriculture
}

\section{Discussion Paper No. 10377 \\ November 2016}

\author{
IZA \\ P.O. Box 7240 \\ 53072 Bonn \\ Germany \\ Phone: +49-228-3894-0 \\ Fax: +49-228-3894-180 \\ E-mail: iza@iza.org
}

Any opinions expressed here are those of the author(s) and not those of IZA. Research published in this series may include views on policy, but the institute itself takes no institutional policy positions. The IZA research network is committed to the IZA Guiding Principles of Research Integrity.

The Institute for the Study of Labor (IZA) in Bonn is a local and virtual international research center and a place of communication between science, politics and business. IZA is an independent nonprofit organization supported by Deutsche Post Foundation. The center is associated with the University of Bonn and offers a stimulating research environment through its international network, workshops and conferences, data service, project support, research visits and doctoral program. IZA engages in (i) original and internationally competitive research in all fields of labor economics, (ii) development of policy concepts, and (iii) dissemination of research results and concepts to the interested public.

IZA Discussion Papers often represent preliminary work and are circulated to encourage discussion. Citation of such a paper should account for its provisional character. A revised version may be available directly from the author. 


\section{ABSTRACT}

\section{Small-Scale Farming and Food Security: The Enabling Role of Cash Transfers in South Africa's Former Homelands*}

Cash transfers successfully alleviate poverty in many developing countries. South Africa is a case in point, implementing one of the largest unconditional cash transfer programmes internationally, and with substantial benefits to household well-being along multiple dimensions. Yet, grants discourage formal labour market attachment, creating dependencies on the fiscus. This study uses a fuzzy regression discontinuity design to establish that statefunded Old Age Pensions encourage non-market economic activity (in the form of small-scale farming), and improve the self-reported food security of rural households that farm, vis-à-vis those that do not. However, only non-farming households increase market food expenditure and consume more diverse diets from market-sourced foods: diet quality improves with greater spending, while food sufficiency remains unaffected. Farmers, on the other hand, do not change food spending patterns, but self-rated food sufficiency improves due to greater levels and diversity in home production. The role of small-scale farming is of broader interest in rural development, given the context of the 1913 and 1936 Land Acts that constrained this form of livelihood in former apartheid homelands. This paper's contribution is two-fold: grants are an effective channel to actively promote rural development through small-scale farming, and they improve food security by non-market mechanisms.

JEL Classification: Q12, Q18, Q15, D13, C26

Keywords: $\quad$ cash transfers, small-scale farming, food security, South Africa, Apartheid homelands, regression discontinuity design

Corresponding author:

Dieter von Fintel

Department of Economics

University of Stellenbosch

Private Bag X01

Matieland, 7600

Republic of South Africa

E-mail: dieter2@sun.ac.za

\footnotetext{
* The authors gratefully acknowledge the useful comments of Hans Binswanger, Michael Aliber, Jorge Aguero, Cally Ardington, Martin Wittenberg, Silvia Napolitano, Anton Ehlers, Debra Shepherd, Servaas van der Berg, Nick Vink, Lulama Traub and Jan Greyling, as well as other participants at the International Conference of Agricultural Economists, the Microeconomic Analysis of South African Data conference, the Agricultural Economics Association of South Africa conference and seminars in the Research on Socioeconomic Policy and Laboratory for the Economics of Africa's Past groups at Stellenbosch University. We gratefully acknowledge funding from Economic Research Southern Africa who published a prior version of this paper as ERSA Working paper 647. Errors remain our own.
} 


\section{NON-TECHNICAL SUMMARY}

Public expenditure on South Africa's cash transfer (or social grants) programme is one of the most extensive (as a proportion of GDP) among developing countries. Most evaluations of this large-scale policy focus on how grants change individuals' incentives to enter or exit the labour market (with conflicting results), while others focus on the benefits for childrens' health and educational outcomes. No studies have considered the role that grants play in promoting informal economic activity, especially in contexts of high unemployment and poverty. New research that focuses specifically on their role in small-holder farming fills this gap.

South Africa's National Development Plan prioritises rural economic development, with technical support to small-scale farmers proposed as one way to achieve this. Small-scale farmers remain largely concentrated in former apartheid homelands, where poverty and unemployment are also most severe nationally. Similarly, social grant recipients are also largely concentrated in these regions. This research asks whether the two policies are complementary: does social grant receipt provide necessary incomes to promote the uptake of and investment in small-scale farming in former apartheid homelands, and can food security be improved if households opt to farm?

Farming households in the former homelands do not enjoy the same access to salary incomes and credit as households that do not embark on any agricultural activities. They therefore generally face resource constraints that would, presumably, also limit their ability to invest in small-scale farming. Instead, they report their main source of income to be derived from social grants. It appears, therefore, that small-scale farming is a necessary supplementary activity to obtain food when market income is lacking and households rely on cash transfers. Turning the question around, however, is it possible that the cash injection from grants can promote farming activity and improve food security? International evidence suggests that this is possible, but only when complementary interventions are also pursued. By contrast, South African transfer recipients are not required to participate in any other programmes, so that the anticipated effects could be zero.

Limiting ourselves to homelands households that live on tribal lands, we first establish that the state-funded Old Age Pension (OAP) causally raises the probability of household farming. There is no evidence to suggest that household members exited the formal labour market to instead start farming. In other words, the increase in home production arises among households that would otherwise not have worked or farmed, so that the additional farmers represent new informal economic activity. How is this achieved? Especially among households headed by women, the cash injection from the OAP was invested in fertilizer for the purposes cultivation. Other unmeasured inputs may have also increased in response to the income, though this cannot be firmly established by the data used.

Importantly, farming and non-farming households' food security situation in these regions changes in different ways in response to incomes from grants. Non-farming households report zero changes in self-reported hunger rates when they receive income from the OAP; however, they do report more expensive food purchases in the marketplace and greater diversity in the food groups contained in their diets (which indicates improved nutrition). Overall, this slightly wealthier group used the cash injection to improve the quality of their diets by buying more food types, while maintaining their levels of food consumption. To the contrary, farming households reported reductions in self-reported hunger, indicating that more food was available for consumption. However, no shifts in the levels or diversity of their market purchases could be detected. Instead, the monetary value of their own production increased, as did the number of food groups they could consume from their yields. 
Food security improved for both farming and non-farming households when they receive transfer income. However, the ability of farming households to achieve this position with limited access to salary income and without changing food purchasing patterns, illustrates that this positive impact can be achieved even in regions where labour and product markets are thin. Should the investment in household agriculture resulting from the grant ensure yields in multiple seasons, the food security benefits may additionally extend to the long run rather than only stimulating immediate purchases. Cash transfers therefore have a role to play in promoting rural development, despite the fact that they are unconditional in nature. 


\section{Introduction}

Publicly funded cash transfers effectively reduce poverty and improve socioeconomic conditions in many developing countries (Schultz, 2004; Ardington et al., 2013; Filipski et al., 2015; Gertler et al., 2012; Macours et al., 2012; Schady \& Rosero, 2008). However, many assessments focus on direct welfare outcomes (such as health or education), or whether the injected income frees resources that allow households to access formal labour and product markets. This study turns the focus to whether cash transfers raise non-market home production, with potential long-run benefits for consumption. Our study context, South Africa, has high unemployment rates and, relative to other developing countries, low rates of participation in the informal sector and household agriculture (Kingdon \& Knight, 2004). We therefore question whether cash injections can assist in creating informal economic activity when the formal labour market is slack and in a setting where segregation legislation limited the extent of home production as an alternative livelihood to salary incomes. Additionally, we consider the effects of transfers that are unconditional in nature, with the possibility that other household spending priorities may crowd out investment in home production.

Hoddinott et al. (2012) contend that cash transfer programmes are usually effective at meeting short-run household food needs (through market consumption), but may not promote investment in agricultural activities that improve long-run self-sufficiency. This is particularly true in the case where complementary interventions or conditionality must be in place to achieve long-term benefits. However, this study contends that even unconditional cash transfers can be effective at increasing the prevalence of small-scale farming in a setting of high unemployment, which in turn has the potential to support food security over the long run. We show this by using data 
from the former apartheid homelands, regions of South Africa that remain highly impoverished, have high concentrations of cash transfers among households and also represent the greatest prevalence of subsistence farmers in the country.

The role that small-scale agriculture should play in economic development remains disputed, with 2014 having marked the international year of the family farm (Christiaensen et al., 2010). While economic growth may be driven by modernising sectors, others maintain that the poor tend to benefit directly from subsistence agriculture (even if this does not stimulate aggregate economic activity). Subsistence activity is therefore postulated to be pro-poor and reduces inequality. Concerns with feeding an estimated worldwide population of 9 billion by 2050 have again placed the focus on the role of small-scale agriculture to create sustainable livelihoods, curtail food insecurity and create employment in rural areas (Machethe, 2004; Dercon, 2009; Birner \& Resnick, 2010).

In South Africa this sector has been handpicked to drive development in rural areas, particularly in the former apartheid homelands. These regions were the only legally designated parts of South Africa where black households could farm, as stipulated by the 1913 and 1936 Land Acts. The legacy of these now-abandoned pieces of legislation remains a central contention in the current public discourse. The National Development Plan (NDP) has earmarked the small-scale farming sector to create 370000 improved livelihoods in the former homeland regions (NPC, 2011).

However, it is well known that the 4 million-strong (traditionally black African) small-scale sector in homeland areas only produces about 5\% of agricultural output, compared to the 35000 (traditionally white) commercial farmers who produce the rest (Aliber \& Hart, 2009). Because of limited capacity, some critics oppose proposals in the NDP to promote small-holder farming as a vehicle for development and poverty alleviation. Sender (2016:18), for instance, emphasises 
small-holders' “...insignificant contribution to food availability and national output” (emphasis added). This stance, however, ignores the potential of the sector to combat food insecurity among the poorest households. Palmer \& Sender (2006) estimate that in 2001 only 3\% of rural households sold more than $25 \%$ of their produce, with another $44 \%$ of the population engaging in "subsistence" activity ${ }^{1}$. Some constraints include the rise of a small elite that has dominated the sector in the former homelands, with substantial portions of land remaining fallow (Sender, 2012; Sender, 2016). Specific food production projects apparently do not improve food security in these regions (Sender, 2016). Small farmers reportedly do not consume more nutritious diets than other rural households, or substantially raise incomes from own production (Palmer \& Sender, 2006). However, cash transfers and households cultivation in food gardens in the former homelands are both positively correlated with lower self-reported hunger levels (Pienaar \& von Fintel, 2014). This paper investigates whether - despite the constraints - cash transfers interact with household production to improve food security.

South Africa has a well-developed social assistance system, which is widely known for its success in targeting the poor and its mitigating impact on poverty (van der Berg et al., 2010). Recipients are most concentrated in the homelands regions where poor small-scale farmers are also still dominantly located. Of the eight available social grants, the old age pension (OAP) remains the best researched and documented, due to the substantial amounts that accrue to households monthly (Neves et al., 2009). This unconditional cash transfer is means-tested and is only targeted at individuals who are no longer considered to be of working age. Evidence suggests that the OAP positively impacts household well-being (Ardington \& Lund, 1995), improves food security (Case \& Deaton, 1998; Pienaar \& von Fintel, 2014; Duflo, 2003;

\footnotetext{
${ }^{1}$ The data used in this study indicate that in 2008/9 approximately $6.6 \%$ of homelands households sold at least some of their produce, while another $31.6 \%$ engaged in farming activity without selling.
} 
D’Agostino et al., 2016), mitigates impacts of HIV/Aids (Booysen, 2004), enables migration to urban labour markets (Posel et al., 2006) and more recently have been shown to promote job search among younger rural household members (Ardington et al., 2013). Each of these studies shows that social assistance directly improves household well-being, while the latter also suggests that second-round benefits arise due to the economic activity that cash transfers generate. Cash transfers therefore enable the poor to integrate into formal markets by encouraging the movement of some household members from slack to tight local labour markets (Posel et al., 2006). This stands in contrast to other studies, which suggest that labour supply reduces in response to receiving OAPs: poor households are apparently becoming more dependent on the fiscus than on income generated in the labour market (Bertrand et al., 2003; Ranchod, 2006; Abel, 2013). Posel et al. (2006), however, emphasise that conclusions differ because of household definitions that are used by various survey data: if non-resident migrants (who were sent by rural households) are considered as a part of the household, labour supply increases in response to the OAP; on the other hand, resident (rural) household members appear to be less attached to the formal labour market in response to the OAP. In the latter case, many such household members live in high unemployment rural areas. Be that as it may, it remains unclear whether cash grants are enablers in small-scale (non-market) farming activities within rural homeland areas, where formal jobs are scarce and poverty is high.

This paper fills this gap by estimating whether the OAP in South Africa contributes to the ability of rural households to pursue small scale farming activities, using a well-known regression discontinuity design that results from the age-eligibility criteria of this unconditional cash grant (Duflo, 2003; Bertrand et. al., 2003; Ranchod, 2006). It continues to assess whether grants have a direct or indirect impact on food security, by estimating their effect on self-reported hunger levels within farming and non-farming households respectively. We find that grants causally 
increase the probability of farming, without substitution away from formal employment among resident household members. Households that do farm report lower levels of hunger in response to receiving income from the OAP. This is not the case for non-farming households. Among farming households, additional income from the OAP increases neither market expenditure on food, nor dietary diversity from market consumption; it does, however, raise output and dietary diversity from home production. Self-reported hunger in farming households is therefore mitigated by non-market activity; this is in turn supported by cash transfers that are not spent on food purchases in the market. Transfers have no positive effects on labour supply and home work decisions, but some evidence suggests that they aid the acquisition of farming inputs. Among non-farming households, food expenditure levels and dietary diversity improve in response to OAP receipts, but in this case all food is purchased from the market. Additional spending on food does not coincide with reductions in self-reported hunger, but does improve the quality of diets.

Hence, subsistence farming is enabled through the OAP and improves food security through nonmarket channels. These benefits are likely to have longer lasting impacts than the case of nonfarmers, who improve their diets by spending more in the market in the short-run. The rest of this paper starts with a review of the impacts of cash grants on socio-economic outcomes, and the role of small-scale farming in rural livelihoods. The subsequent section outlines data and methods used, followed by a discussion of results and our conclusions.

\section{Cash transfers in developing countries}

Cash transfers have been implemented by many developing countries in order to improve the lives of the poor. In South Africa, this programme has been particularly large, with close to 16.6 million recipients (of which nearly 3.1 million were awarded as OAP’s) by 2015 (South African 
Social Security Agency, 2015). As a proportion of GDP, South Africa’s cash transfer programme ranks among the largest in the world (van der Berg et al., 2010). In general, South African social grants are a means of redistributing income to directly impact poverty and inequality in both its incidence and severity (Inchauste et al., 2015). Furthermore, cash transfers also have intangible impacts: they foster social cohesion and improve human capital development (Jacobs et al., 2010). Grants also display positive externalities by impacting health and housing positively, while also seemingly supporting informal economic activities (Altman et al., 2008; Neves et al., 2009).

Collective international evidence also suggests that cash transfers have positive impacts on socio-economic outcomes in many different contexts. A focal point of this literature is the positive effects that they have on food security and nutrition. In defiance of the Engel curve, the income shock from cash grants increases food budget shares in Ecuador (Schady \& Rosero, 2008). Other forms of income do not induce the same type of behaviour, with food shares typically declining with income from other sources. Cash grants therefore prompt specific changes to expenditure patterns that are beneficial to households. In various other contexts (ranging from Mexico, Nicaragua to South Africa) cash transfers have been found to improve childhood development, particularly through the channel of improved nutrition (Macours et al., 2012; Fernald et al., 2009; Duflo, 2003; Coetzee, 2013, d'Agostino et al., 2016).

Nutrition can improve either due to direct spending in food markets, or because transfers also promote non-market home food production. Only limited evidence exists to support the latter mechanism. Randomised control trial evidence from Mexico suggests that approximately 25\% of cash transfers are re-invested into productive activity that directly raises household agricultural output (Gertler et al., 2012). While most of the cash grant is immediately consumed in the market, a sizable proportion stimulates long-run subsistence consumption that results from 
small-scale farming activity. Similarly, Tanzanian households increased investments in livestock, while they did not spend additional grant money on market food expenditure (Evans et al., 2014). Hence, cash transfers have the potential to improve livelihoods and food security through the promotion of own account economic activity, in particular through investment in small-scale farming.

In South Africa, the proposed channel through which cash transfers improve food security is usually presumed to be through direct market expenditure, or through the grants' role in enabling formal labour market attachment. Yet, the extensive social grant system has in many instances been found to reduce labour supply and employment (Bertrand et al., 2003; Ranchod, 2006; Abel, 2013). While some attribute this to the elderly that exit the formal labour market (reportedly to retire and care for the children of prime-aged labour force participants), others do find that the extra income frees the young to migrate from their rural homes and embark on job search in urban areas (Ardington et al., 2013; Ardington et al., 2009; Posel et al., 2006). Yet, no study considers the role that grants play in improving rural livelihoods through household farming activity. As the next section argues, small-scale farming is a historically neglected and depressed sector in rural South Africa. Cash transfers can, however, potentially re-invigorate this type of livelihood and involvement in this activity can provide explanations for their povertyreducing effects in rural areas.

\section{The proposed role of small-scale farming in supporting food security}

\subsection{Smallholder agriculture in the former apartheid homelands}

While Fields (2011) emphasises the importance of small-scale agriculture in most developing countries (where formal labour markets are too small to absorb the entire labour force into employment) this alternative form of livelihood generation is more constrained in South Africa 
than the rest of the continent. The agricultural sector in South Africa is characterised by a dualistic structure (Vink \& Kirsten, 2003). A division between the commercial, large-scale farming sector and the comparatively low productive, struggling small-scale sector is only partially a manifestation of economies of scale. Rather, this phenomenon is a direct result of historical patterns of dispossession and impoverishment, which systematically eroded historically successful land-based production systems and livelihoods in South Africa (Neves et al., 2009). Thus, a small-scale farmer today is typically black, landless, poor, farms on very small pieces of (communal) land for household subsistence and the majority of farmers depend on social grants payments from the government's social protection programme (Fenyes \& Meyer, 2003; Groenewald \& Nieuwoudt, 2003; Lahiff \& Cousins, 2005). By all existing indications, then, this is a non-buoyant sector, characterised by dependency, rather than being enabled by social programmes. Critics go as far as claiming that policies should not consider this form of livelihood as a poverty-reducing tool (Sender, 2016; Sender, 2012; Palmer \& Sender, 2006).

Agriculture continues to be characterized by inequality in terms of the distribution of economic assets, support services, market access, infrastructure and income (Oettle et al., 1998). Nevertheless, the sector remains an important livelihood activity among the dwindling rural South African population, with the majority of households directly or indirectly involved in farming (Machethe, 2004; Pauw, 2007). Recent estimates from Statistics South Africa’s 2013 General Household Survey suggest that 51\% of all households in tribal (former homeland) areas are directly involved in farming activities, while the absolute number of farming households in former homelands has increased from 2.28 million in 2003 to 2.68 in 2013 . The increase is matched by a large rise in social grants over the same period, particularly within the homelands regions. This begs the question whether grants have enabled subsistence activity, or whether increasingly impoverished small-scale farmers are forced to rely on transfer income. These 
households improve livelihoods for many residents, supplementing the source of food within their respective communities that are plagued by high levels of unemployment.

\subsection{Linkage between social grants and farming}

We turn to the formal link between cash grants and their impact on agriculture specifically. Small-scale food production contributes modestly to income, emphasizing its subsistence characteristic (Palmer \& Sender, 2006). Furthermore, declining proportions of households rely on salary incomes and remittances from family members in recent years, and publicly funded social transfers have become a dominant source of income (Cousins, 2013). Figure 1 illustrates the potential grant dependence of households in former homeland areas. Approximately $50 \%$ of farming households list transfers as their main source of livelihood. On the other hand, nonfarmers depend on salary incomes, though grants are still the main source for more than $30 \%$ of this group.

While these figures may suggest that cash transfers lead to dependency, recent research investigates its benefits for agriculture. Lewis et al. (2011) show that the introduction of social grants in the Mbongolwane Wetland (in KwaZulu-Natal) area played a catalytic role in the development from a largely subsistence, resource-based local economy to a strongly commercial, cash-based economy. Furthermore, these grants were said to boost households' purchasing power indirectly and provided capital for farmers to start businesses. Individuals receiving old age pensions continued to pursue land-based livelihoods. The younger generation was clearly unwilling to take up these farming activities (Lewis et al., 2011), but other evidence suggests that they become enabled to enter urban labour markets due to the resources now available to households (Ardington et al., 2009; Ardington et al., 2013). 
The rest of this paper distinguishes between the dependency and enabling hypotheses, by finding causal estimates of grants on farming and food security. We isolate the channels by which farmers are able to create better livelihoods.

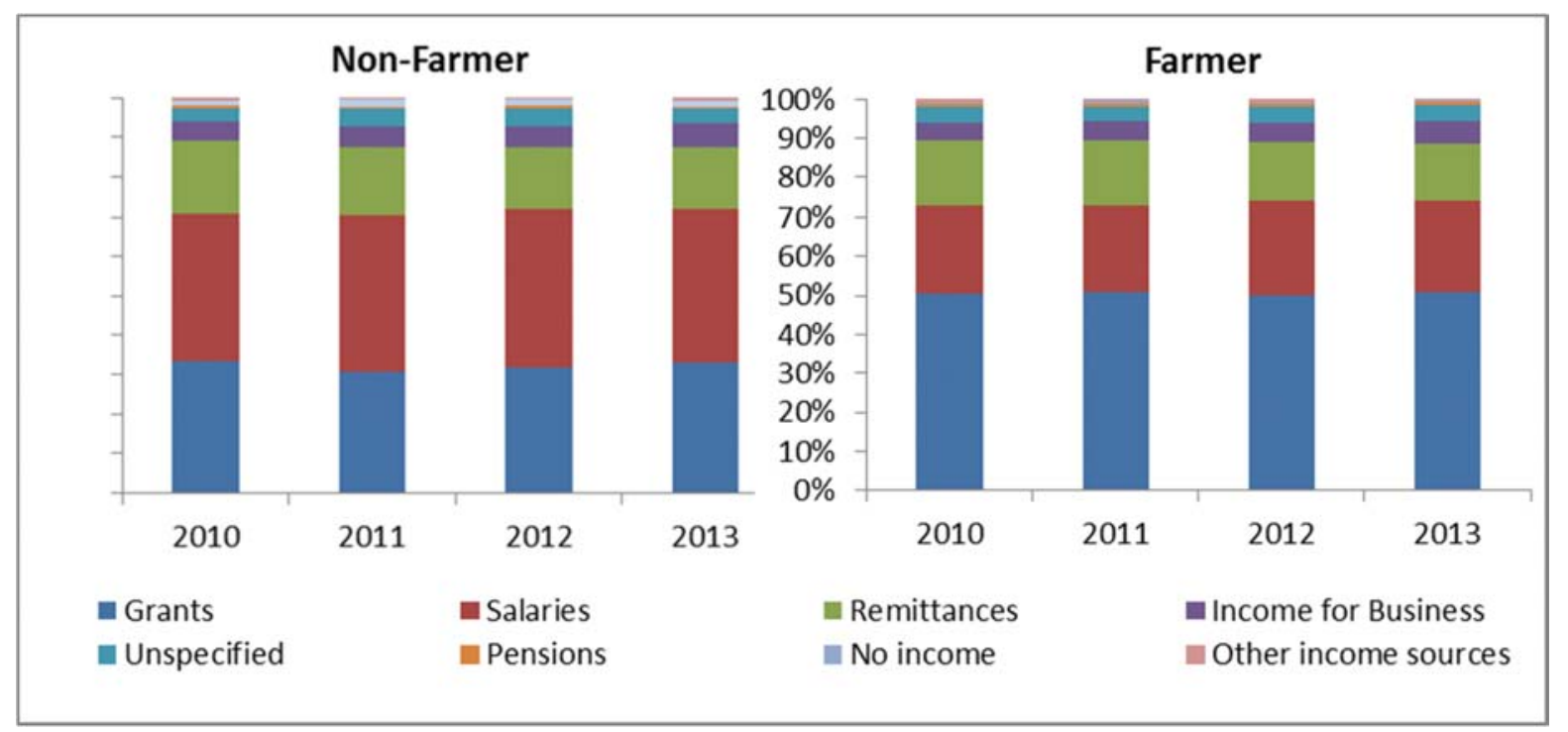

Figure 1 Black African homeland households' main income sources, by farming status. Source: Own calculations from General Household Survey, 2010-2013

\section{Data and Methodology}

\subsection{Data}

The data utilized in this paper is the nationally representative Living Conditions Survey (LCS) survey, conducted by Statistics South Africa during 2008 and 2009 (Statistics South Africa, 2008/09). It included 25075 households, with questions on household income and expenditure, subjective poverty, assets and more importantly, detailed information on small-scale farming. The latter remains limited in many other sources, but this survey allows for successful differentiation between farming households and non-farming households. The questionnaire continues to collect detailed information on income and, more specifically, cash transfers (Statistics South Africa, 2008/09). 
We sample households residing within the boundaries of South Africa's former homeland areas, as demarcated by the Natives’ Land Acts of 1913 and 1936 (Pienaar, 2013). Most subsistence farming activity is concentrated in these regions. Former homelands constitute $13 \%$ of the total land area of South Africa. These areas were developed separately during the most part of the previous century and remain distinct in their economic characteristics to this day.

We furthermore limit ourselves to tribal areas within former homelands, because these areas have been targeted for the expansion of small-scale farming as a means of increased livelihood activity. As a result, we exclude urban areas and also avoid including commercial farmers who do not operate on tribal lands. These areas are also the poorest and receive a large concentration of social transfers. We also restrict ourselves to the black African subpopulation, as this group was directly affected by the imposition of the Land Acts and other apartheid policies that enforced separate development.

Small-scale farmers are identified based on their responses to the question on whether or not the household produced any agricultural produce during the previous 11 months. In every instance, farmers reported farming on small pieces of land in the chosen region.

\subsection{Methodology}

The causal impact of South Africa's social grants have been identified using multiple methods, including propensity score matching (Coetzee, 2013; Aguero et al., 2007), panel data methods (Ardington et al., 2013; Ardington et al., 2009; Abel, 2013) and a fuzzy regression discontinuity design (RDD) (Duflo, 2003; Bertrand et al., 2003; Ranchod, 2006; d’Agostino, 2016; Ranchhod \& Wittenberg, 2016).

This paper takes the latter approach. RDD’s have become an increasingly popular tool to identify causal effects in social sciences, and are relatively easy to interpret (Imbens \& Lemieux, 2008; 
Angrist \& Pischke, 2009). In this case, the age of the household head is the continuous running variable. Beyond stipulated thresholds (as discussed below) income is shocked due to a rulebased external policy or eligibility criteria. Households just below that threshold and just above it are, for all intents and purposes, similar, except that they fall on either side of the policy eligibility criteria. This separates respondents into a neat treatment and control group around the cut-off point. Any large differences in outcome variables around the threshold are plausibly caused by the external "rule" only ${ }^{2}$. In the case of the OAP, a clear age-eligibility criteria is in place, alongside means testing. Households with a head above the threshold age are in the treatment group, as the home's decision-maker qualifies for the OAP only because they have become older ${ }^{3}$. Heads below that age are mostly excluded. The question in this analysis is whether the propensity to embark on small scale farming and food security outcomes also change around the age eligibility criteria, so much so that we can causally attribute this to OAP receipt.

At the time of the survey used in this data, only women above the age of 60 , and men above the age of 61 or 63 (depending on the time of the interview) were considered for receipt of the OAP. Initially men only qualified from the age of 65: however, a 2008 Constitutional Court ruling progressively lowered this threshold during the time that the LCS was enumerated, to converge on the criteria for women by 2010 (Department of Social Development, 2008). While the means test further restricts eligibility, about $90 \%$ of individuals in the relevant age range receive this grant in rural South Africa, so that age is the primary criteria for being treated (Ardington et al., 2013; Ardington et al., 2009).

\footnotetext{
${ }^{2}$ Ardington et al., (2009), however, show that household composition changes when a household receives or loses a grant over time. We study such confounding factors in our robustness checks. ${ }^{3}$ We use the age of the household head as running variable instead of the age of the oldest person in the household. In 93\% of households the two definitions coincide. In other cases, we presume that an OAP recipient who is not the oldest household member will also not make decisions about farming and food expenditure. Therefore, we opt for the first definition.
} 

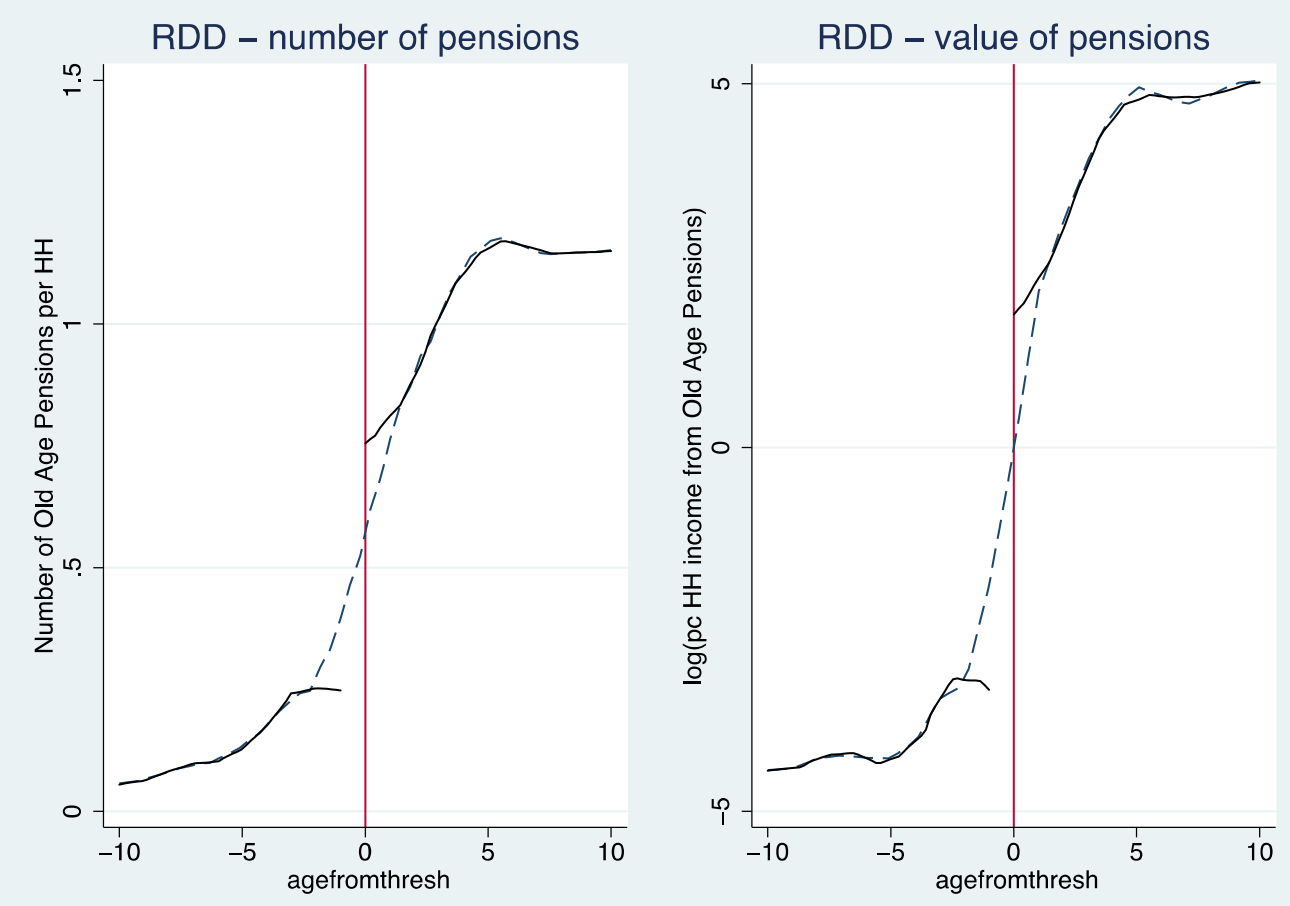

Figure 2 Discontinuity in Old-Age Pension Take-up. Source: Own Calculations from LCS (2008/9)

Figure 2 shows the discontinuity in both the number of pensions and total household income from the OAP that arises when the household head crosses the relative threshold (at 0 years from eligbility; negative values indicate that the head is younger than the eligible age, and positive values indicate being older). The jump is not sharp, because many younger individuals also live in households with pension recipients and benefit from this type of income. This household formation pattern is common in rural areas, whereby the unemployed tend to congregate in households with pensioners (Klasen \& Woolard, 2009).

Typically fuzzy RDD’s are estimated using Two-Stage Least Squares (2SLS), with the threshold serving as the exogenous instrument to identify causal effects. The first stage models the total income that the household receives from the OAP, as a function of the head's age, while the second stage estimates the responsiveness of various indicators to this income. 


$$
\begin{gathered}
\log \left(\widehat{O A P}_{i}\right)=\hat{\alpha}_{0}+\hat{\alpha}_{1} a g e_{i}+\hat{\alpha}_{2} I\left(\text { age } e_{i}>\text { threshold }\right)+\hat{\alpha}_{3} a g e_{i} * I\left(\text { age }_{i}>\text { threshold }\right)+\delta^{\prime} x_{i} \\
y_{i}=\hat{\beta}_{0}+\hat{\beta}_{1} \log \left(\widehat{O A P}_{i}\right)+\gamma^{\prime} x_{i}+\hat{\varepsilon}_{i}
\end{gathered}
$$

where $y$ is the outcome of interest and $\hat{\beta}_{1}$ is the required causal effect. The first stage can be estimated with polynomials in age, interacted with the threshold indicator. Such an approach is necessary if the relationship between the running variable and the endogenous variable is nonlinear around the threshold. We do not show results that follow this approach, as they are similar to the linear specification.

The RDD strategy is most effective at reducing bias if conducted on a sub-sample close to the threshold; conversely, limiting the sample to a region in the data that is concentrated too close to the cut-off may result in imprecise estimates. On balance, we choose a sample of households whose heads are 10 years younger and older than the eligibility criteria. We present extensive robustness checks to show that our results are stable across samples that include older and younger individuals.

While recent research conducted in Lesotho shows that local spillovers also benefit non-recipient households (Filipski et al., 2015), these community-level externalities are not explored here. As a result, the effects noted in this study are potentially understated, and could be larger than reported. Yet, given the widespread coverage of the OAP in former homelands, spillover effects are likely to be less important in this context.

We limit ourselves to study the OAP, as its income is sizable compared to other grants and sources of income, amounting to roughly twice the per capita black income (Bertrand et al., 2003). In 2008, when the survey used in this study was collected, the monthly payout stood at R940 (about US\$120) per recipient. Exploiting the fuzzy RDD apparent in the data, we study the 
effect of the OAP on the probability of being a farmer, and also on various food security outcomes in former apartheid homeland regions. We also uncover the channels through which farmers maximise the benefits of the transfers vis-à-vis non-farmers: we consider whether the cash is spent on direct market expenditure, on inputs into the production process, or whether it relieves individuals from formal labour market work in order to focus on hunger-reducing home production.

\section{Results}

Table 1 indicates the substantive socioeconomic differences between households that have at least one OAP recipient and those with none, as well as between those that farm and those that do not. Transfers are correctly targeted towards households with lower per capita income. As noted above, farming households are more reliant on transfer income than non-farmers, who have greater access to salary streams. Farming and OAP recipient households share the characteristics of less educated heads, fewer household members in employment outside the home and significantly more household members work in home production. Farmers' access to credit is substantially lower than that of non-farmers.

Ironically, non-farmers are closer to food markets and have better access to water infrastructure (though the former difference is not statistically significant). Non-farmers are close to food markets for consumption purposes, while those who do cultivate lands are likely doing so for subsistence purposes rather than for selling at the market. Farmers' self-rated poverty is marginally lower than non-farmers. Overall, then, farmers seem to be initially poorer and supplement their livelihoods with subsistence activity in the absence of substantial labour market income. Despite these differences, reported hunger levels are not significantly different across 
groups, indicating that this livelihood strategy is successful at bridging welfare gaps to ensure food security. We investigate the role that the transfer income plays in bridging this gap. 
Table 1 Household differences by OAP receipt and farming status

\begin{tabular}{|c|c|c|c|c|c|c|}
\hline & $\begin{array}{l}\text { OAP } \\
\text { Recipient }\end{array}$ & $\begin{array}{l}\text { Non- } \\
\text { recipient }\end{array}$ & Difference & Farmer & $\begin{array}{l}\text { Non- } \\
\text { Farmer }\end{array}$ & Difference \\
\hline Per capita monthly household income (Rands) & 594.07 & 995.59 & $-401.52 * * *$ & 652.61 & 970.75 & $-318.14 * * *$ \\
\hline Per capita monthly income from OAP (Rands) & 283.01 & 0.00 & $283.01 * * *$ & 104.10 & 64.33 & $39.77 * * *$ \\
\hline Per capita monthly household income from salaries (Rands) & 161.80 & 684.64 & $-522.85 * * *$ & 276.03 & 639.79 & $-363.76 * * *$ \\
\hline Per capita access to immediate credit (Rands) & 70.50 & 157.39 & $-86.89 * * *$ & 92.40 & 149.49 & $-57.09 * * *$ \\
\hline Education of head (years) & 2.97 & 7.57 & $-4.60 * * *$ & 5.26 & 6.74 & $-1.49 * * *$ \\
\hline Proportion of heads female & 0.63 & 0.51 & $0.12 * * *$ & 0.57 & 0.53 & $0.04 * *$ \\
\hline Proportion of heads married & 0.36 & 0.46 & $-0.10 * * *$ & 0.52 & 0.41 & $0.12 * * *$ \\
\hline Household size & 5.55 & 4.21 & $1.33 * * *$ & 5.53 & 4.24 & $1.30 * * *$ \\
\hline Distance to food market (m) & 398.97 & 397.58 & 1.39 & 413.18 & 392.90 & 20.28 \\
\hline Proportion of households with access to piped water & 0.48 & 0.55 & $-0.07 * * *$ & 0.37 & 0.58 & $-0.21 * * *$ \\
\hline Number of household members employed in last week & 0.35 & 0.59 & $-0.24 * * *$ & 0.40 & 0.57 & $-0.17 * * *$ \\
\hline Number of non-recipient household members employed in last week & 0.32 & 0.59 & $-0.27 * * *$ & 0.39 & 0.57 & $-0.18 * * *$ \\
\hline Number of household members employed in last year & 0.42 & 0.67 & $-0.26 * * *$ & 0.49 & 0.64 & $-0.16^{* * *}$ \\
\hline Number of non-recipient household members employed in last year & 0.38 & 0.67 & $-0.30 * * *$ & 0.47 & 0.64 & $-0.17 * * *$ \\
\hline Number of household members that work on a plot & 0.54 & 0.30 & $0.24 * * *$ & 1.03 & & \\
\hline Number of non-recipient household members that work on a plot & 0.32 & 0.30 & 0.01 & 0.84 & & \\
\hline Number of household members that work in the home & 1.77 & 1.27 & $0.49 * * *$ & 2.14 & 1.16 & $0.98^{* * *}$ \\
\hline Number of non-recipient household members that work in the home & 1.27 & 1.27 & -0.01 & 1.86 & 1.08 & $0.79 * * *$ \\
\hline Proportion rating themselves as poor & 0.14 & 0.14 & 0.00 & 0.12 & 0.15 & $-0.03^{* *}$ \\
\hline Proportion reporting child hunger & 0.09 & 0.09 & 0.00 & 0.10 & 0.09 & 0.01 \\
\hline Proportion reporting adult hunger & 0.09 & 0.10 & -0.01 & 0.11 & 0.09 & 0.01 \\
\hline
\end{tabular}

NOTES: own calculations from LCS 2008/9. All households in tribal areas within former apartheid homelands regions are included. Estimates are weighted. * p<0.1, $* * \mathrm{p}<0.05, * * * \mathrm{p}<0.01$ 


\subsection{The causal effect of OAP income on the probability of farming}

We start with the question of whether farming households are reliant on grant income for additional livelihood, or whether the OAP enables households to pursue non-market farming activities. We limit ourselves to households whose heads are aged within 10 years of the eligibility threshold, but conduct robustness checks below.

Table 2 Linear Probability Model for the propensity to engage in farming activities

\begin{tabular}{llll} 
& $P($ Farming $)$ & $P($ OAP $)$ & $P($ Farming $)$ \\
\cline { 2 - 4 } & OLS & 2SLS first stage & 2SLS second stage \\
\hline log(per capita income from OAP) & $0.009^{* * *}$ & & $0.012^{* * *}$ \\
$\log ($ per capita income from salaries) & -0.004 & $-0.056^{* * *}$ & -0.004 \\
$\log ($ per capita income from other sources) & $0.011^{* *}$ & -0.034 & $0.011^{* *}$ \\
$\log ($ per capita access to credit) & $0.007^{* *}$ & -0.012 & $0.007^{* *}$ \\
HH head education & -0.001 & -0.014 & 0.000 \\
HH head education squared & 0.000 & -0.005 & 0.000 \\
HH head is female & -0.030 & -0.028 & -0.029 \\
HH head is married & $0.054^{*}$ & 0.141 & $0.057^{*}$ \\
log(HH size) & $0.068^{* * *}$ & 0.102 & $0.067^{* * *}$ \\
Distance to food market $<750 m$ & -0.031 & -0.136 & -0.031 \\
Distance to food market 0.75-1.5km & -0.053 & -0.317 & -0.052 \\
Distance to food market 6-15km & 0.007 & -0.217 & 0.008 \\
Distance to food market $>15 \mathrm{~km}$ & -0.025 & -0.172 & -0.026 \\
Access to piped water & $-0.182^{* * *}$ & -0.127 & $-0.183^{* * *}$ \\
Age from eligibility threshold & & $0.129 * * *$ & \\
Above age eligibility threshold & & $5.123^{* * *}$ & \\
Age from threshold * above threshold & & $0.241^{* * *}$ & \\
Constant & $0.294^{* * *}$ & $-2.906^{* * *}$ & $0.294^{* * *}$ \\
\hline R-squared & 0.082 & 0.666 & 0.081 \\
N & 1603 & 1603 & 1603 \\
Hausman p-value & & & $0.068^{*}$ \\
First stage F statistic & & 948.871 & \\
\hline \hline
\end{tabular}

NOTES: own calculations from LCS 2008/9. Only households with heads whose ages are 10 years above or below the pension eligibility threshold and living in rural tribal areas are included in the sample. Estimates are weighted. * $\mathrm{p}<0.1, * * \mathrm{p}<0.05, * * * \mathrm{p}<0.01$ 
OLS results in Table 2 suggest that a 1 percentage point increase in per capita income from the OAP is associated with an approximately 0.9 percent increase in a household's probability to engage in farming. Yet, these results cannot distinguish between the two lines of causality noted above. Fuzzy RDD estimates in the third column are higher at 1.2 per cent, and now give the causal impact of transfer income on pursuing farming activity (and not the other way around). Figure 3 shows that the probability of farming jumps at the age eligbility threshold, so that the impacts we measure can be attributed causally to pension receipt. The instrument is strong, with a first stage F statistic of 948.871 (much larger than the rule of thumb of 10), and the Hausman test on the second stage rejects that the OLS and RDD estimates are equivalent. The first stage regression shows that crossing the threshold substantially raises the probability of receiving the OAP. A similar first stage regression is used in all subsequent 2SLS results, but is not shown again. The downward bias of the OLS coefficient indicates that poorer farmers select into social grant receipts, as was also indicated by the descriptive analysis in Table 1.

We briefly discuss the importance of some of the control variables. Notably, salary incomes are associated with a lower probability of farming (though the coefficient is not statistically significant). Households that are attached to the labour market therefore tend to select out of farming, so that the activity represents a coping strategy in the absence of salary income. Our result also suggests that salary income is not used to overcome any constraints to start farming, but is sufficient for securing livelihoods. Income from other non-labour sources and credit availability, on the other hand, tend to ease credit constraints and motivate individuals to farm. Larger households are significantly more likely to participate, ,so that small-holder farming represents a livelihood coping strategy when large families are not adequately supported by other forms of income. More importantly than their effects, each of these factors controls for the confounding effects of changes in other household circumstances when a member receives an 
OAP. Younger household members become empowered by the OAP income to migrate and seek jobs in urban regions (Ardington et al, 2009), while the long-term unemployed return to the pension households to be supported by this type of income (Klasen \& Woolard, 2009). Consequently some households become more integrated into the formal labour market as a result of OAP receipt, while other households that are isolated from the job market over the long-run grow when they receive transfer income. Our results suggest that the former type of household becomes less reliant on farming, while the latter type of household becomes more dependent on subsistence activity to sustain growing households. We explore these mechanisms in greater detail below, when we directly model the effects of transfer income on changes in market and home employment.

A control for access to piped water is introduced to account for potential selection on infrastructure and access to service delivery that may be essential to home production: households that are generally poorly resourced choose to farm, supporting the notion that this type of activity supports subsistence living rather than production for market purposes. The rest of this paper will only focus on the coefficient of interest (income from the OAP), departing from the variables considered in this paragraph.

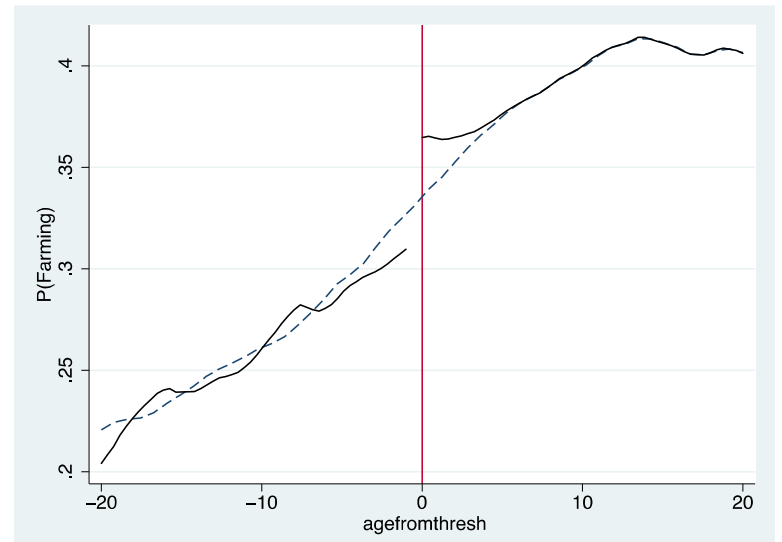

Figure 3 Discontinuity in probability of farming around age threshold. Source: Own Calculations from LCS (2008/9) 


\subsection{The causal effect of OAP income on food security}

We rely on a number of indicators to assess whether households are food secure in response to receiving the OAP. The first considers whether households report that children or adults have sufficient food to meet their needs. Clearly this measure has many shortcomings and cannot be studied in isolation. Firstly, self-reported hunger is subjectively reported and prone to measurement error. What one household reports as "enough” may be considered insufficient by another. Secondly, having sufficient food - even if accurately reported - does not fully encapsulate food security conceptually: importantly, if household members are to maintain healthy lives, the correct combination of food groups from a diverse diet is necessary. Hence, we construct dietary diversity measures to extend our understanding of whether the OAP improves the quality of nutrition among farmers and non-farmers.

We begin our assessment of food security with results in Table 3 estimating the impact of income from the OAP on self-reported hunger levels of children, differentiated by households' farming status. We split the sample to assess whether the OAP income has a more elastic effect on food security among farming households vis-à-vis those that rely on labour market incomes. Child hunger is defined as a dummy variable that indicates when a household reports that any child was hungry "often" or "always". Below we will consider more objective measures of food security.

The instruments are again strongly correlated with the endogenous variables (with particularly high first stage F statistics), and the Hausman test suggests that they differ from OLS estimates in the case of farmers. Whilst salary incomes are associated with lower prevalence of selfreported child hunger, the coefficients are not statistically significant. In contrast, coefficients on 
OAP income are substantially larger in absolute value, and are aditionally statistically significant for the OLS estimates. Studying the causal 2SLS estimates, non-farming households do not report significantly lower levels of child hunger when they receive additional OAP income (the effect is less than half a per cent and cannot be statistically differentiated from zero). Conversely, in farming households income from the OAP significantly reduces self-reported child hunger at the $1 \%$ level of significance. Therefore only farming households experience hunger reductions after receiving the cash transfer. The effect is quantitatively large for this group, with a $1 \%$ increase in per capita income from the OAP reducing the probability of child hunger by $1.2 \%$. Should an additional person cross the age eligibility threshold in an existing one-pensioner household, reported child hunger would be eliminated among farming households, but not among non-farming households. Similar results are obtained for adult hunger, with income from the OAP only causally reducing self-reported hunger in farming households.

Given that the OAP prompted households to pursue small-scale farming operations, these results suggest that a channel through which income support alleviates reported child hunger in the homelands is through subsistence cultivation. 
Table 3 Linear Probability Models of the prevalence of adult hunger

\begin{tabular}{|c|c|c|c|c|c|c|c|c|}
\hline & \multicolumn{4}{|c|}{$P($ Child Hunger $)$} & \multicolumn{4}{|c|}{ P(Adult Hunger) } \\
\hline & Non-Farmer & Farmer & Non-Farmer & Farmer & Non-Farmer & Farmer & Non-Farmer & Farmer \\
\hline & OLS & OLS & 2SLS & 2SLS & OLS & OLS & 2 SLS & $2 \mathrm{SLS}$ \\
\hline log(p.c. income: OAP) & $-0.005^{* *}$ & $-0.007 * *$ & -0.004 & $-0.012 * * *$ & $-0.007 * * *$ & $-0.007 * *$ & -0.004 & $-0.011 * * *$ \\
\hline $\log$ (p.c. income: salaries) & -0.001 & -0.003 & -0.001 & -0.004 & -0.002 & -0.003 & -0.002 & -0.004 \\
\hline log(p.c. income: other) & -0.006 & 0.006 & -0.005 & 0.005 & -0.003 & 0.007 & -0.003 & 0.007 \\
\hline $\log$ (p.c. access to credit) & 0.001 & 0.002 & 0.001 & 0.002 & -0.001 & 0.003 & -0.001 & 0.003 \\
\hline HH head education & -0.011 & -0.006 & -0.010 & -0.007 & -0.008 & 0.003 & -0.007 & 0.002 \\
\hline HH head education ${ }^{2}$ & 0.000 & 0.000 & 0.000 & 0.000 & 0.000 & $-0.001^{*}$ & 0.000 & $-0.001^{*}$ \\
\hline HH head is female & -0.005 & $-0.100 * *$ & -0.004 & $-0.105^{* *}$ & -0.023 & $-0.131 * * *$ & -0.022 & $-0.134 * * *$ \\
\hline $\mathrm{HH}$ head is married & $-0.059 * *$ & $-0.093^{*}$ & $-0.057 * *$ & $-0.099 * *$ & $-0.056^{* *}$ & $-0.140 * * *$ & $-0.054 * *$ & $-0.144 * * *$ \\
\hline $\log (\mathrm{HH}$ size $)$ & $0.107 * * *$ & 0.017 & $0.106 * * *$ & 0.018 & $0.048 * * *$ & 0.006 & $0.047 * * *$ & 0.006 \\
\hline \multicolumn{9}{|l|}{ Distance to food market: } \\
\hline$<750 \mathrm{~m}$ & 0.021 & -0.037 & 0.020 & -0.040 & 0.01 & -0.046 & 0.01 & -0.048 \\
\hline $0.75-1.5 \mathrm{~km}$ & 0.054 & -0.057 & 0.055 & -0.057 & 0.044 & -0.033 & 0.044 & -0.032 \\
\hline 6-15km & $-0.057 * *$ & -0.017 & $-0.057 * *$ & -0.017 & -0.035 & -0.026 & -0.034 & -0.025 \\
\hline$>15 \mathrm{~km}$ & 0.025 & 0.073 & 0.024 & 0.071 & 0.044 & 0.069 & 0.043 & 0.067 \\
\hline Access to piped water & -0.032 & -0.02 & -0.033 & -0.02 & $-0.036 *$ & 0.000 & $-0.037 *$ & 0.001 \\
\hline Constant & 0.003 & $0.202 * *$ & 0.004 & $0.211^{* * *}$ & $0.115^{* * *}$ & $0.233 * * *$ & $0.117 * * *$ & $0.241^{* * *}$ \\
\hline R-squared & 0.065 & 0.067 & 0.065 & 0.062 & 0.05 & 0.074 & 0.048 & 0.071 \\
\hline $\mathrm{N}$ & 843 & 450 & 843 & 450 & 1035 & 507 & 1035 & 507 \\
\hline Hausman p-value & & & 0.293 & $0.041^{* *}$ & & & 0.136 & $0.073 *$ \\
\hline First stage F statistics & & & 568.983 & 365.602 & & & 496.347 & 391.088 \\
\hline
\end{tabular}

NOTES: own calculations from LCS 2008/9. Only households with heads whose ages are 10 years above or below the pension eligibility threshold and living in rural tribal areas are included in the sample. Estimates are weighted. ${ }^{*} p<0.1,{ }^{* *} \mathrm{p}<0.05, * * * \mathrm{p}<0.01$ 
Table 4 2SLS Regressions modelling food consumption and production patterns

\begin{tabular}{|c|c|c|c|c|c|c|c|c|}
\hline & \multicolumn{4}{|c|}{ Market Consumption } & \multicolumn{4}{|c|}{ Home Production } \\
\hline & \multicolumn{2}{|c|}{$\log ($ per capita food exp) } & \multicolumn{2}{|c|}{ Dietary Diversity } & \multirow{2}{*}{\begin{tabular}{|l}
$\log$ (output) \\
Farmer
\end{tabular}} & \multirow{2}{*}{\begin{tabular}{|l} 
DDS \\
Farmer
\end{tabular}} & \multirow{2}{*}{$\begin{array}{l}\text { log(fertilizer) } \\
\text { Farmer }\end{array}$} & \multirow{2}{*}{\begin{tabular}{|l}
$\log ($ tools $)$ \\
Farmer
\end{tabular}} \\
\hline & Non-Farmer & Farmer & Non-Farmer & Farmer & & & & \\
\hline & 2SLS & 2SLS & 2SLS & 2SLS & 2SLS & 2SLS & $2 S L S$ & 2SLS \\
\hline log(p.c. income: OAP) & "0.016*** & 0.001 & $0.017^{*}$ & 0.011 & $0.095 * *$ & $0.013^{* *}$ & 0.046 & 0.029 \\
\hline $\log$ (p.c. income: salaries) & $0.009 * *$ & $0.016^{* * *}$ & 0.015 & $0.046 * * *$ & 0.005 & -0.006 & -0.008 & -0.011 \\
\hline $\log$ (p.c. income: other) & $0.016^{* *}$ & $0.022 * *$ & $0.033 * *$ & $0.056^{* *}$ & 0.006 & -0.002 & $-0.145^{* *}$ & 0.018 \\
\hline $\log$ (p.c. access to credit) & 0.000 & 0.005 & 0.002 & 0.003 & 0.028 & 0.006 & 0.016 & 0.018 \\
\hline HH head education & 0.006 & -0.001 & $0.054 *$ & -0.001 & 0.024 & -0.005 & -0.024 & 0.049 \\
\hline HH head education ${ }^{2}$ & 0.001 & 0.002 & -0.003 & 0.003 & 0.000 & 0.001 & $0.017^{*}$ & -0.001 \\
\hline HH head is female & 0.033 & 0.036 & 0.136 & -0.085 & 0.015 & -0.032 & -0.528 & 0.171 \\
\hline $\mathrm{HH}$ head is married & $0.174^{* * *}$ & $0.128^{*}$ & 0.081 & 0.076 & 0.434 & 0.055 & 0.122 & 0.398 \\
\hline $\log (\mathrm{HH}$ size $)$ & $-0.528 * * *$ & $-0.602 * * *$ & $0.458 * * *$ & $0.351 * * *$ & $-0.991 * * *$ & 0.009 & 0.386 & 0.055 \\
\hline \multicolumn{9}{|l|}{ Distance to food market: } \\
\hline$<750 \mathrm{~m}$ & -0.051 & -0.041 & -0.044 & 0.232 & -0.131 & -0.023 & 0.733 & $0.393 *$ \\
\hline $0.75-1.5 \mathrm{~km}$ & 0.072 & 0.064 & 0.069 & 0.26 & -0.555 & -0.063 & 0.890 & $0.770^{*}$ \\
\hline 6-15km & $0.142^{*}$ & 0.114 & $0.308^{*}$ & $0.467 * *$ & 1.199 & 0.200 & 0.683 & $0.826^{*}$ \\
\hline$>15 \mathrm{~km}$ & $0.120 * *$ & 0.039 & $0.302 * *$ & 0.05 & -0.042 & -0.036 & 0.418 & 0.195 \\
\hline Access to piped water & $0.068 *$ & $-0.101 *$ & -0.077 & $-0.237^{*}$ & $0.853^{* *}$ & 0.090 & $-2.059 * * *$ & -0.068 \\
\hline Constant & $8.213^{* * *}$ & $8.495 * * *$ & $4.941^{* * *}$ & $5.349 * * *$ & $-3.359 * * *$ & 0.188 & -0.871 & $-5.031 * * *$ \\
\hline R-squared & 0.272 & 0.310 & 0.091 & 0.093 & 0.046 & 0.039 & 0.107 & 0.037 \\
\hline $\mathrm{N}$ & 1081 & 522 & 1081 & 522 & 522 & 522 & 522 & 522 \\
\hline Hausman p-value & 0.516 & 0.486 & 0.983 & 0.874 & 0.761 & 0.707 & 0.968 & 0.059 \\
\hline First stage F statistics & 535.792 & 402.800 & 535.792 & 402.800 & 402.800 & 402.800 & 402.800 & 402.800 \\
\hline
\end{tabular}

NOTES: own calculations from LCS 2008/9. Only households with heads whose ages are 10 years above or below the pension eligibility threshold and living in rural tribal areas are included in the sample. Estimates are weighted. ${ }^{*} \mathrm{p}<0.1,{ }^{* *} \mathrm{p}<0.05,{ }^{* * *} \mathrm{p}<0.01$ 
We now turn to more objective measures of food security. We first investigate changes to market expenditure on food across farming and non-farming households. In particular, the aim is to disinguish whether the additional income was spent directly on immediate consumption in the market, or whether farming households achieved this by using OAP income to cultivate their own food. Should transfers not be spent on market purchases (particularly by farming households), then they are, by implication, spent on investments in non-market food production that in turn reduces self-reported hunger. As noted above, evidence from other settings suggests that this particular channel raises consumption expenditure over the long-run, and not only in the short-run (Gertler et al., 2012). We therefore also test whether the estimated monetary value of food output from farmers' own production increases in response to the cash transfer, supporting long-run improvements in consumption levels ${ }^{1}$. Additionally, the analysis uses measures of dietary diversity ${ }^{2}$, both from food bought in the market place and produced on own plots, to understand whether nutrition quality improved instead of only having enough.

Table 4 starts with models of per capita food expenditure (in other words, the value of food that is bought on the market only, excluding that which is home-produced for own consumption) ${ }^{3}$. Transfer income only significantly raises food expenditure in non-farming households, while the impact is small and statistically insignificant in farming households.

\footnotetext{
${ }^{1}$ Many farming respondents reported zero value of home production, so that under-reporting is likely to attenuate coefficients towards zero. We nevertheless present these estimates to aid the discussion.

${ }^{2}$ A very simple dietary diversity score, measured from 0 to 7 , indicates the number of COICOP food groups that the household consumed (from the market or home production, respectively) ${ }^{3}$ We do not show OLS results from here on. They are qualitatively similar to RDD estimates, as attested to by the mostly insignificant Hausman tests.
} 
Among households that are reliant on salary incomes, the OAP promotes direct market expenditure on food, without the need for additional home production. Given that self-reported hunger did not also decrease for this group, the higher OAP elasticity on food expenditure for this sub-sample implies that food security improved along another dimension beyond the levels of intake. The third and fourth columns indicate that dietary diversity from market-acquired food, as with expenditure levels, only improved among the non-farming group. Together, the results therefore emphasise that households with access to some salary income are not "forced" to farm; they also do not necessarily buy more food; rather, they use additional income from cash transfers to improve the quality of their diets by expanding food baskets to more expensive products.

In farming households the pattern differs in important ways. Market consumption does not increase, nor does the variety of the market food basket. However, levels and diversity of home production both increase significantly in response to OAP income (as shown in the second panel of Table 4). Despite potential downward bias that may arise from under-reported estimates of home production, the effect on farmers' home production levels is quantitatively much larger than the impact on non-farmers' market consumption levels. More vulnerable households are therefore more likely to farm when transfer incomes increase, raise food consumption and diversity through home production and consequently improve self-reported food security and nutritional quality. This large effect occurs outside the market context (both in terms of food consumption and production), and emphasises the complementary role of cash transfers and small-holder agriculture in bolstering food security. Importantly, this result is achieved for an unconditional cash transfer, unlike in other settings where complementary programmes were required (Hoddinott et. al., 2012). 


\subsection{Channels}

The mechanisms through which cash transfers improve food security differ for farmers and nonfarmers. In the first case, we speculate that the effect is more obvious than in the second case: less vulnerable households spend the additional transfer cash in the market to improve diet quality, not food amounts. The mechanisms in the second case are less clear, but more policy relevant, and will be uncovered in greater detail. As highlighted in section 5.1., transfers appear to be compensating for a lack of salary income in the decision to farm; other forms of non-labour income tend to do the same. One potential explanation, therefore, is that small-holder farmers are capital constrained and do not have funds to invest in the inputs of home production. Alternatively, however, we also noted that larger households are more likely to farm and that grants tend to attract other unemployed household members. A second potential explanation for the large effects of transfers among farming households is, therefore, that the long-run unemployed exit the labour market and assist elderly recipients in successful home production. Ranchod (2006) has already shown that the elderly withdraw from the labour market in response to receiving the OAP. Cash transfers therefore potentially introduce substitution between market and non-market economic activity.

Subsequent analysis therefore focusses on farming households to distinguish whether they employed more capital inputs (fertilizer and tools) or labour inputs to achieve greater food security.

The last two columns of table 4 consider capital constraints among farmers. While a $1 \%$ increase in OAP income raises fertilizer expenditure by approximately $4.6 \%$, this estimate is not significantly different from zero. Similarly, pension income raises the asset value of tools used 
for cultivation, but not significantly. Evidence to suggest that the acquisition of new agricultural inputs with OAP income is therefore limited ${ }^{4}$.

We therefore turn to changes in labour market behaviour in response to receiving the OAP as an explanation. Table 5 presents various models of the number of wage employed household members as a function of transfer income. Because grants may prompt retirement among the age-eligible (Ranchhod, 2006), we also exclude recipients from total household employment in some specifications. Results that exclude recipients therefore focus on the behaviour among the young. The first column of the table supports the evidence of Ardington et. al. (2009), where employment in the prior week among non-farmers increases in households that receive the OAP. The effect is, however not significant. No other statistically significant effects are measured, except for a reduction in non-recipient wage employment in the last year among farmers. The reference period of one year points to a long-run withdrawal from the wage-paying labour market that is not attributable to a retirement effect.

\footnotetext{
${ }^{4}$ Again, underreporting (with many reported zeroes) may be reducing precision, so that it is not possible to conclude whether the null effects are real or a statistical artefact.
} 
Table 5 2SLS Regressions modelling wage employment

\begin{tabular}{|c|c|c|c|c|c|c|c|c|}
\hline & \multirow{2}{*}{\multicolumn{4}{|c|}{ log(HH members wage employed in last week) }} & \multirow{2}{*}{\multicolumn{4}{|c|}{ log(HH members wage employed in last year) }} \\
\hline & & & & & & & & \\
\hline & \multicolumn{2}{|c|}{ Including pensioner } & \multicolumn{2}{|c|}{ Excluding pensioner } & \multicolumn{2}{|c|}{ Including pensioner } & \multicolumn{2}{|c|}{ Excluding pensioner } \\
\hline & Non-Farmer & Farmer & Non-Farmer & Farmer & Non-Farmer & Farmer & Non-Farmer & Farmer \\
\hline & 2SLS & 2SLS & 2SLS & 2SLS & 2SLS & 2SLS & 2SLS & 2SLS \\
\hline log(p.c. income: OAP) & 0.007 & -0.009 & -0.002 & -0.023 & -0.006 & $\begin{array}{l}-0.021 \\
\end{array}$ & -0.017 & $-0.040 * *$ \\
\hline $\log$ (p.c. income: salaries) & $0.377 * * *$ & $0.387 * * *$ & $0.372 * * *$ & $0.369 * * *$ & $0.400 * * *$ & $0.414^{* * *}$ & $0.394 * * *$ & $0.393 * * *$ \\
\hline $\log$ (p.c. income: other) & -0.002 & 0.001 & -0.008 & -0.002 & 0.017 & -0.001 & 0.009 & -0.007 \\
\hline $\log ($ p.c. access to credit) & 0.003 & -0.004 & 0.000 & -0.010 & -0.002 & -0.012 & -0.002 & -0.017 \\
\hline HH head education & -0.032 & 0.029 & -0.034 & 0.019 & 0.003 & 0.02 & 0.001 & -0.016 \\
\hline HH head education ${ }^{2}$ & $0.003^{*}$ & -0.001 & $0.003^{*}$ & 0.000 & -0.001 & -0.002 & -0.001 & 0.001 \\
\hline $\mathrm{HH}$ head is female & -0.035 & 0.078 & -0.012 & -0.032 & 0.001 & 0.094 & 0.04 & -0.052 \\
\hline $\mathrm{HH}$ head is married & -0.057 & 0.105 & -0.033 & 0.037 & -0.122 & 0.035 & -0.098 & 0.026 \\
\hline $\log (\mathrm{HH}$ size $)$ & $0.384 * * *$ & $0.256 * * *$ & $0.399 * * *$ & $0.265^{* * *}$ & $0.226 * * *$ & $0.290 * * *$ & $0.252^{* * *}$ & $0.338^{* * *}$ \\
\hline \multicolumn{9}{|l|}{ Distance to food market: } \\
\hline$<750 \mathrm{~m}$ & 0.042 & 0.162 & 0.05 & 0.134 & 0.092 & -0.212 & 0.115 & -0.218 \\
\hline $0.75-1.5 \mathrm{~km}$ & 0.093 & 0.115 & 0.107 & -0.068 & -0.18 & -0.176 & -0.145 & -0.318 \\
\hline 6-15km & -0.104 & 0.054 & -0.174 & 0.04 & -0.021 & -0.106 & -0.1 & -0.242 \\
\hline$>15 \mathrm{~km}$ & 0.045 & 0.095 & 0.014 & 0.085 & 0.014 & -0.119 & 0 & -0.119 \\
\hline Access to piped water & 0.068 & 0.055 & 0.073 & 0.132 & 0.057 & -0.052 & 0.058 & -0.003 \\
\hline Constant & $-3.222 * * *$ & $-3.390 * * *$ & $-3.261 * * *$ & $-3.376 * * *$ & $-2.867 * * *$ & $-2.837 * * *$ & $-2.943 * * *$ & $-2.842 * * *$ \\
\hline R-squared & 0.74 & 0.76 & 0.736 & 0.737 & 0.766 & 0.796 & 0.761 & 0.768 \\
\hline $\mathrm{N}$ & 1081 & 522 & 1081 & 522 & 1081 & 522 & 1081 & 522 \\
\hline Hausman p-value & 0.373 & 0.257 & 0.349 & 0.212 & 0.483 & 0.328 & 0.789 & 0.618 \\
\hline First stage F statistics & 535.792 & 402.8 & 535.792 & 402.8 & 535.792 & 402.8 & 535.792 & 402.8 \\
\hline
\end{tabular}

NOTES: own calculations from LCS 2008/9. Only households with heads whose ages are 10 years above or below the pension eligibility threshold and living in rural tribal areas are included in the sample. Estimates are weighted. * $p<0.1, * * p<0.05, * * * p<0.01$ 
Table 6 2SLS Regressions modelling home activity

\begin{tabular}{|c|c|c|c|c|c|c|}
\hline & \multicolumn{2}{|c|}{$\begin{array}{c}\log (\mathrm{HH} \text { members } \\
\text { working on plot) }\end{array}$} & \multicolumn{4}{|c|}{$\log (\mathrm{HH}$ members doing any house work) } \\
\hline & \multirow{2}{*}{$\begin{array}{l}\text { Including } \\
\text { Farmer }\end{array}$} & \multirow{2}{*}{$\begin{array}{l}\text { Excluding } \\
\text { Farmer }\end{array}$} & \multicolumn{2}{|c|}{ Including pensioners } & \multicolumn{2}{|c|}{ Excluding pensioners } \\
\hline & & & Non-Farmer & Farmer & Non-Farmer & Farmer \\
\hline & 2SLS & 2SLS & 2SLS & 2SLS & 2SLS & 2SLS \\
\hline log(p.c. income: OAP) & 0.028 & $-0.087 * * *$ & $-0.040 *$ & 0.000 & $-0.110 * * *$ & $-0.120 * * *$ \\
\hline log(p.c. income: salaries) & 0.012 & 0.014 & $-0.066^{* * *}$ & 0.009 & $-0.059 * * *$ & 0.024 \\
\hline log(p.c. income: other) & 0.056 & 0.064 & -0.002 & 0.000 & -0.003 & 0.009 \\
\hline $\log$ (p.c. access to credit) & $0.053 * *$ & 0.035 & -0.002 & $0.040 * *$ & -0.006 & 0.017 \\
\hline HH head education & 0.115 & $0.163 * *$ & -0.020 & 0.061 & -0.026 & 0.041 \\
\hline HH head education ${ }^{2}$ & -0.005 & -0.008 & -0.004 & -0.005 & -0.003 & -0.003 \\
\hline HH head is female & $-0.780 * *$ & $-0.613 * *$ & 0.160 & $-0.407^{*}$ & 0.115 & $-0.451^{*}$ \\
\hline $\mathrm{HH}$ head is married & 0.091 & -0.062 & 0.006 & -0.102 & -0.111 & -0.265 \\
\hline $\log (\mathrm{HH}$ size $)$ & $0.567 * * *$ & $0.789 * * *$ & $0.586 * * *$ & $0.819 * * *$ & $0.839 * * *$ & $1.472 * * *$ \\
\hline \multicolumn{7}{|l|}{ Distance to food market: } \\
\hline$<750 \mathrm{~m}$ & $-0.622 * *$ & $-0.566^{* *}$ & $0.375^{*}$ & 0.311 & 0.190 & 0.346 \\
\hline $0.75-1.5 \mathrm{~km}$ & $0.819 *$ & $1.110 * * *$ & -0.095 & $0.938 * * *$ & -0.055 & $0.991 * * *$ \\
\hline 6-15km & $0.852^{*}$ & $0.770^{*}$ & -0.290 & $0.521^{*}$ & -0.298 & 0.385 \\
\hline$>15 \mathrm{~km}$ & 0.180 & 0.372 & 0.304 & 0.349 & 0.287 & $0.422 *$ \\
\hline Access to piped water & $-0.740 * * *$ & $-0.682 * * *$ & $-1.206^{* * *}$ & $-0.696 * * *$ & $-1.183^{* * *}$ & $-0.712 * * *$ \\
\hline Constant & $-2.626 * * *$ & $-3.747 * * *$ & $-1.682 * * *$ & $-1.035^{* * *}$ & $-2.265^{* * *}$ & $-2.529 * * *$ \\
\hline R-squared & 0.107 & 0.16 & 0.126 & 0.143 & 0.16 & 0.256 \\
\hline $\mathrm{N}$ & 522 & 522 & 1081 & 522 & 1081 & 522 \\
\hline Hausman p-value & 0.501 & 0.592 & 0.898 & 0.419 & 0.763 & 0.353 \\
\hline First stage F statistics & 402.8 & 402.8 & 535.792 & 402.8 & 535.792 & 402.8 \\
\hline
\end{tabular}

NOTES: own calculations from LCS 2008/9. Only households with heads whose ages are 10 years above or below the pension eligibility threshold and living in rural tribal areas are included in the sample. Estimates are weighted. ${ }^{*} \mathrm{p}<0.1,{ }^{* *} \mathrm{p}<0.05,{ }^{* * *} \mathrm{p}<0.01$ 
Does the withdrawal of non-recipients correspond to a similar increase in engagement in home work? Table 6 shows that grant income has an insignificant positive impact on the number of members working on their own plots for food production. Once recipients are excluded, a significant negative effect appears. The result for all household members is therefore a combination of two opposing effects: OAP recipients become more likely work on their own plots, while other household members become less likely to do so. A similar pattern holds with respect to any work in the household in both farming and non-farming households. While there is limited support for non-recpients' withdrawal from wage employment, they certainly do not change their behaviour to contribute more to home production. This is supported by the results of Ranchhod and Wittenberg's (2016) time use study, which suggests that women recipients increase time spent on care for children, while younger women reduce this figure. Hence, our results suggest that there is no talk of substitution between market and non-market activity. Instead, the burden of increased household labour falls on the transfer recipient. This person has command over the added household resources, but also invests them in home production. While our results do not support that this investment was made in fertilizer or tools, other unmeasured inputs may have been acquired through the cash transfer. Unfortunately the data does not provide sufficient information to establish whether other inputs have increased, though our robustness checks in the next section indicate that women-headed households spend the grant income on fertilizer.

\subsection{Robustness checks}

We conduct robustness checks due to two primary concerns. The first objective relates to coefficient stability and inference, while the second distinguishes whether the measured impacts are driven by the pension directly or retirement more generally. The latter is done by estimating 
the models separately by gender of the household head. Figures 4, 5 and 6 summarise the checks that we conducted.

\subsubsection{Coefficient stability}

All estimates presented in the tables above are conducted using a sample that falls within 10 years of the age threshold. Figure 4 shows a set of RDD estimates that are similar to those presented above, but using various samples. In other words, 5 on the $\mathrm{x}$ axis suggests that all individuals 5 years younger and older than the age cut-off are used in estimation. At 10 a larger age range is included. Smaller bandwidths include fewer observations and reduce precision. However, narrower limits are preferable to ensure that similar individuals just below and above the cut-off are compared in estimation. Overall, conclusions remain robust for larger sample sizes.

In most instances, coefficients grow in size as the sample includes respondents further from the cut-off. This provides a clear indication of selection bias as more dissimilar individuals are compared to each other. However, small sample sizes for bandwidths of below 10 lead to very broad confidence bands, with almost no significant effects. Coefficients and their significance generally remain stable above this point, so that our analysis above is considered credible.

\subsubsection{Gender distinctions}

Figures 5 and 6 re-estimate all effects by gender of the household head. Ranchhod and Wittenberg (2016) show, that at the pension age cut-off men substitute substantial time allocation away from labour market work to home work. An potential objection to our results, therefore, is that all impacts are largely driven by normal transitions into retirement as opposed to the effects of pension income. Fortunately, women's time allocation changes more gradually as they age and does not correspond as closely to OAP eligibility. A separate analysis of women therefore 
confirms whether the measured impacts can be attributed to the pension incomes or retirment more generally.

Most results are similar across sample, so that we are confident that our results are not driven by sudden retirement that is prompted by eligibility for the OAP. One important difference, however, strengthens our results. At acceptable bandwidths, households headed by women use the transfer income to increase fertilizer usage. This confirms our assertion that non-labour inputs constitute the most likely reason for increased home production and food security. 

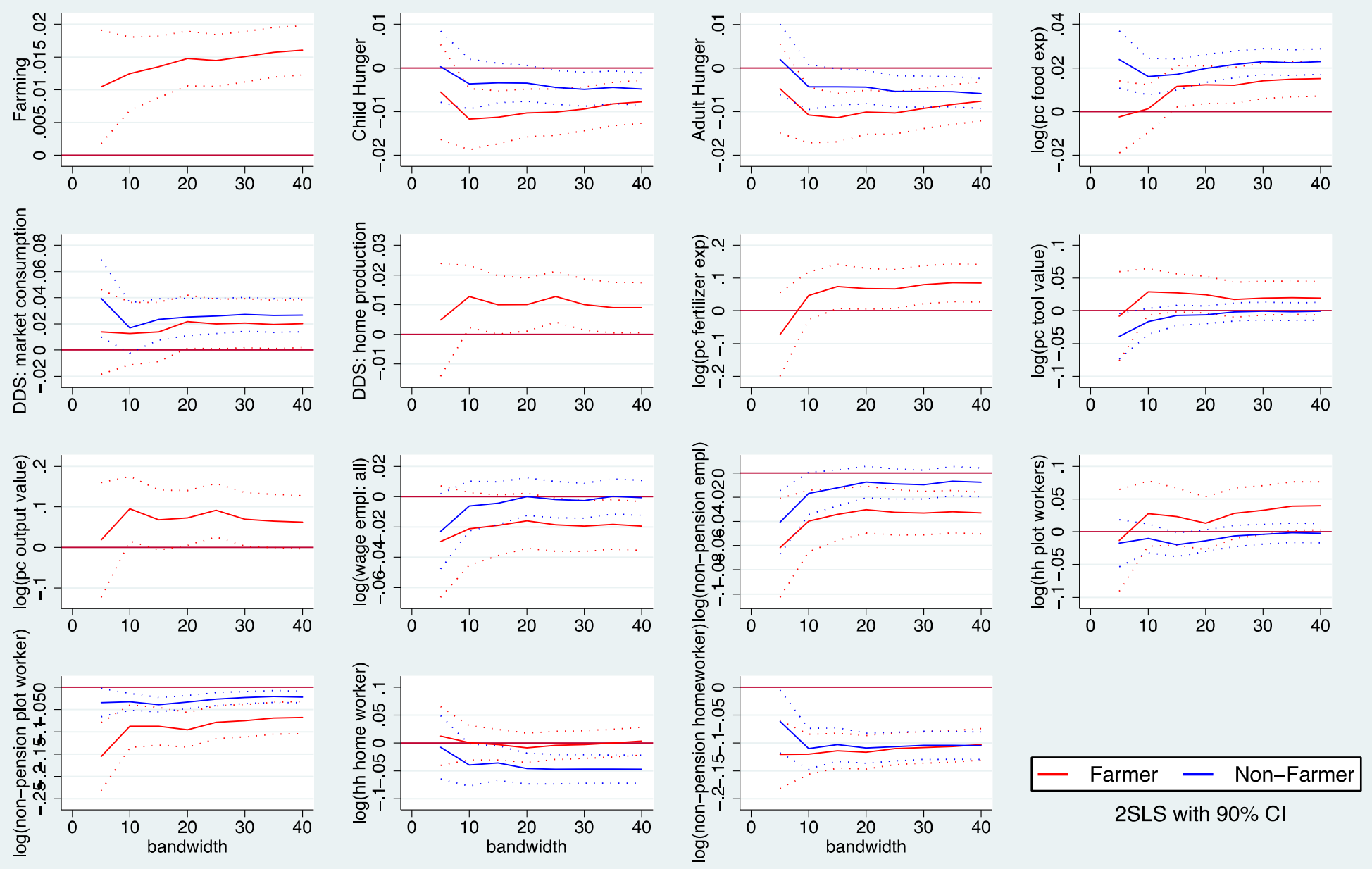

$2 \mathrm{SLS}$ with $90 \% \mathrm{Cl}$

Figure 4 Regression discontinuity coefficients with $90 \%$ confidence intervals at various bandwidths - all households. Source: Own Calculations from LCS (2008/9) 

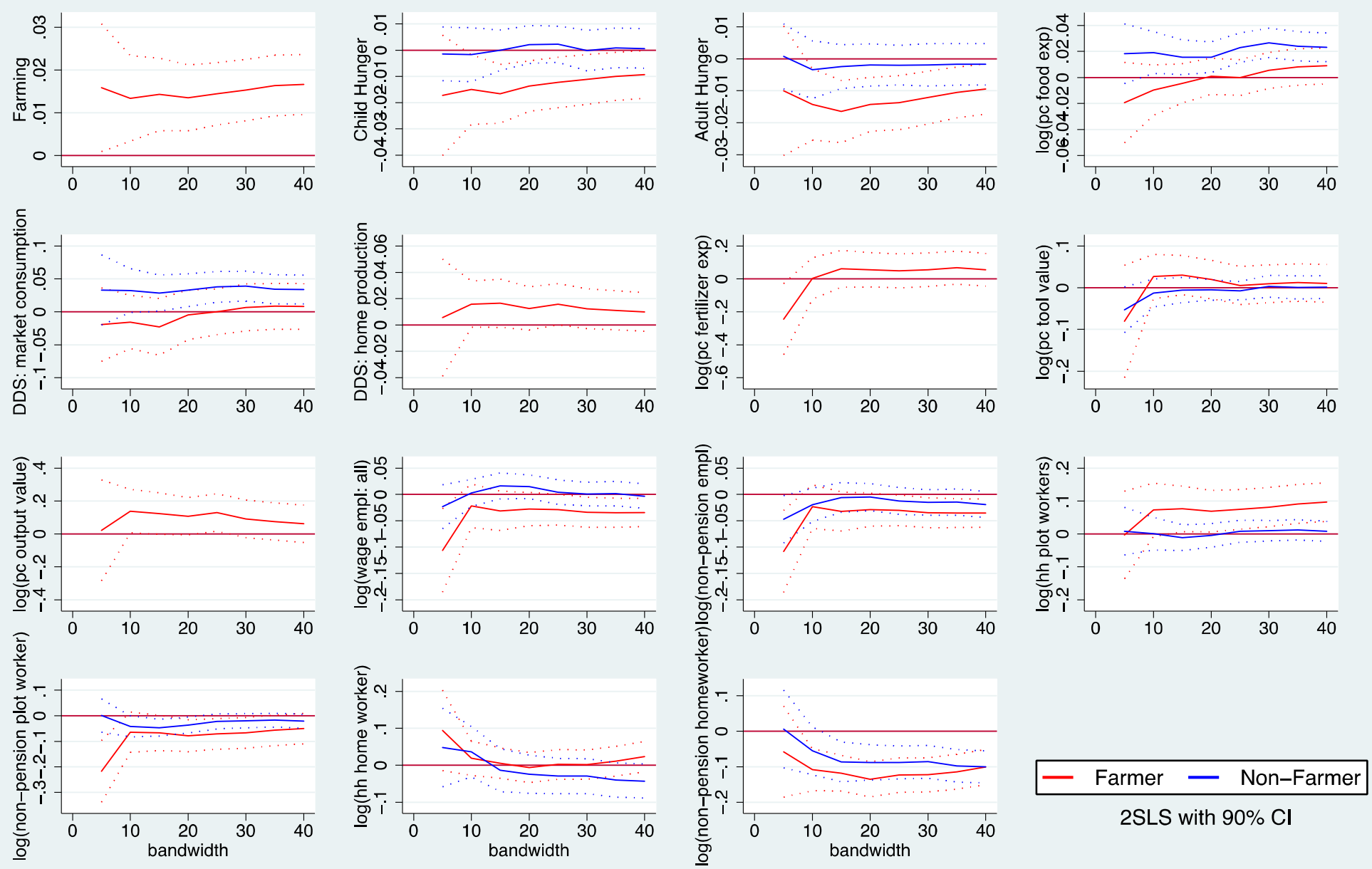

Figure 5 Regression discontinuity coefficients with $\mathbf{9 0 \%}$ confidence intervals at various bandwidths - households headed by men. Source: Own Calculations from LCS (2008/9) 

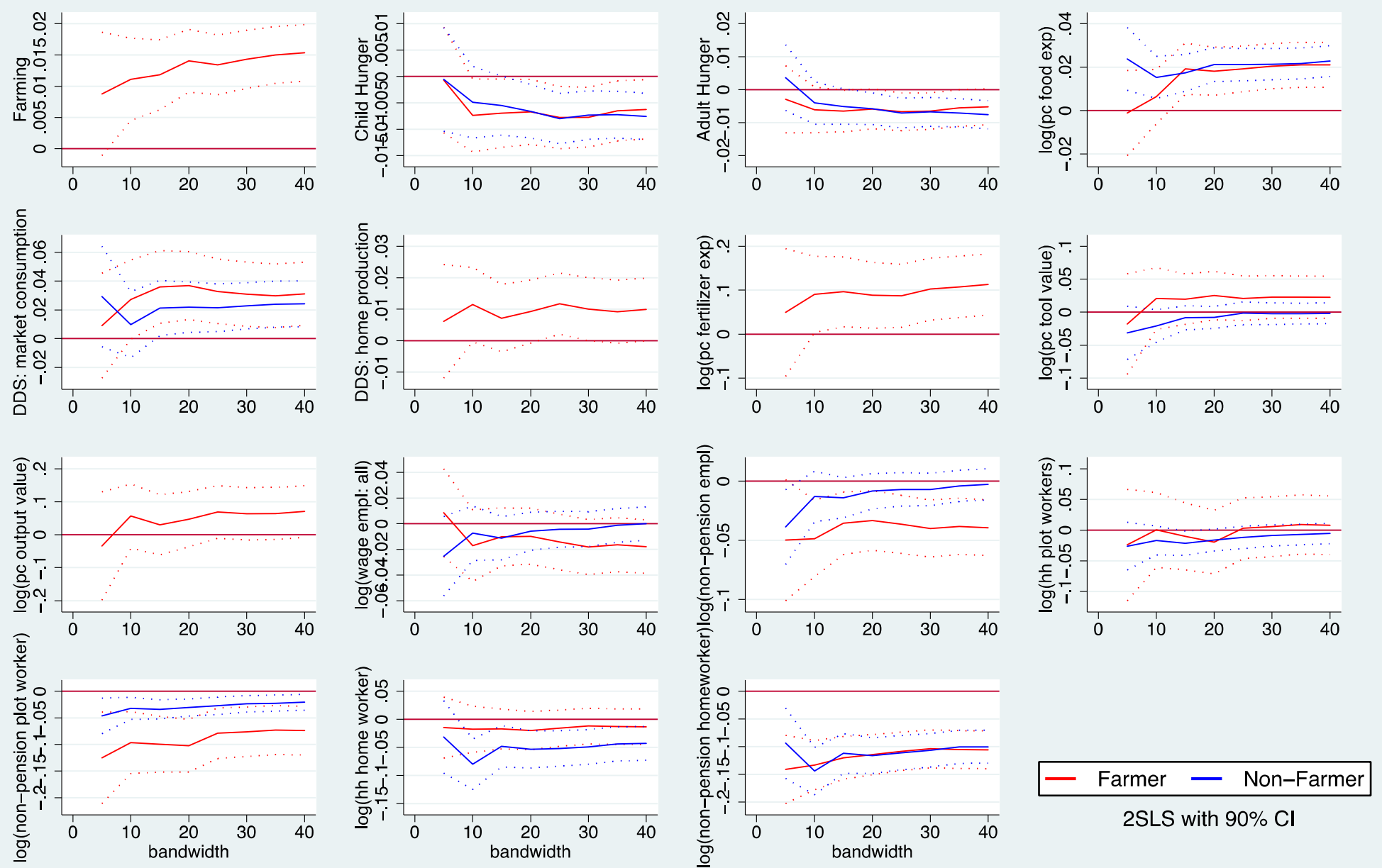

2 SLS with $90 \% \mathrm{Cl}$

Figure 6 Regression discontinuity coefficients with $90 \%$ confidence intervals at various bandwidths - households headed by women. Source: Own Calculations from LCS (2008/9) 


\section{Conclusion}

Our results show that a large unconditional cash transfer in rural South Africa raises the probability of household farming without substitution away from formal employment. While a large number of these farmers exhibit a depend on cash transfers as a main source of income, the amount is used to invest in subsistence economic activity, stimulating food security. The potential for reaping long-run benefits (which cannot be measured here), as noted in other economies, also exists (Gertler et al., 2012). Importantly, these effects are achieved with an unconditional transfer, and in the context of long-run restrictions on small-scale farming in the former apartheid homelands. Therefore, contrary to other settings (Hodinott et al, 2012), complementary interventions are not a prerequisite for positive agricultural effects.

In particular, farming households tend to be larger and have poorer access to food markets and infrastructure. These factors are likely to leave them at greater risk of food insecurity. The income from the OAP is therefore vital to household livelihood, and is invested in farming activities that mitigate the risks of food insecurity. The result is that the relatively low market expenditure on food can be compensated with own production that is funded by the OAP. Income from the OAP reduces self-reported hunger substantially among farming households, alleviating the higher dependency burden within this group. The effect is quantitatively large: one additional pension per household would eliminate self-reported hunger; additionally, farmers' increases in food output in response to transfer income is far greater than the increase in market expenditure on food realised by non-farmers. For these households, the quality of diets improves in response to grant income (instead of the absolute levels of hunger). We establish that there is no substitution away from wage employment to home work to achieve this outcome. To 
the contrary, OAP non-recipients tend maintain employment and reduce engagement in home production. While it is difficult to pinpoint exact mechanisms with the available data, our results show that transfers raise fertilizer usage in women-headed households.

This concurs with past results. Duflo (2003) shows that the OAP improves child outcomes if grandmothers (women in particular) receive transfer income and Coetzee (2013) shows that similar benefits accrue to children due to the Child Support Grant. Our results, however, add substantially to the picture by showing that small-scale farming is one of the important mechanisms through which these benefits arise. Importantly, then, grants improve livelihoods in multiple ways: through direct effects (by, for instance, enabling food expenditure in the market), they promote youth attachment to the labour market to generate additional income (Ardington et al., 2013) and, as we show, they even reach the most resource constrained by allowing them to produce food for own consumption among households with elderly members. Hence, while many rural households depend on grants as a dominant income source, this form of social assistance also enables secondary economic activity.

In a slack labour market with a small informal sector and historical restrictions on land ownership, the relatively low levels of home production are a concern. Our results show that an unconditional cash transfer provides a realistic alternative for households to acquire relevant inputs for food production, without necessarily resorting to thin produce and labour markets. Hence, cash transfers can stimulate economic activity and rural development, even in regions that are isolated from central markets. 


\section{Bibliography}

Abel, M., 2013. Unintended labour supply effects of cash transfer programmes: Evidence from South Africa's old age pension. SALDRU working paper 114. Cape Town: Southern Africa Labour and Development Research Unit.

Aguero, J.M., Carter, M. \& Woolard, I., 2007. The Impact of Unconditional Cash Transfers on Nutrition: The South African Child Support Grant. Working Paper 39. United Nations Development Programme.

Aliber, M. \& Hart, T., 2009. Should Subsistence Farming be Supported as a Strategy to address Rural Food Security. Agrekon, 48(4), pp.434-58.

Altman, M., Boyce \& G, 2008. Policy options to leverage the system of social grants for improved access to economic opportunities. Employment Growth \& Development Initiative.

Angrist, J.D. \& Pischke, J.-S., 2009. Mostly Harmless Econometrics: An Empiricist's Companion. Princeton: Princenton University Press.

Ardington, C., Barnighausen, T., Case, A. \& Menendez, A., 2013. Social protection and labour market outcomes of youth in South Africa. Working Paper 96. Southern Africa Labour Development and Research Unit.

Ardington, C., Case, A. \& Hosegood, V., 2009. Labour supply responses to large social transfers: Longitudinal evidence from South Africa. American Economic Journal: Applied Economics, 1(1), pp.22-24.

Ardington, E. \& Lund, F., 1995. Pensions and development: Social security as complimentary to programmes of reconstruction and development. Development Southern Africa, 12(4), pp.557-77.

Bertrand, M., Mullainathan, S. \& Miller, D., 2003. Public Policy and Extended Families: Evidence from Pensions in South Africa. The World Bank Economic Review, 17(1), pp.27-50.

Birner, R. \& Resnick, D., 2010. The Political Economy of Policies for Smallholder Agriculture. World Development, 38(10), pp.1442-52.

Booysen, F., 2004. Social grants as safety net for HIV/AIDS-affected households in South Africa. Journal of Social Aspects of HIV/AIDS Research Alliance, 1(1), pp.45-56. 
Case, A. \& Deaton, A., 1998. Large cash transfers to the elderly in South Africa. The Economic Journal, 108(450), pp.1330-61.

Christiaensen, L., Demery, L. \& Kuhl, J., 2010. The (evolving) role of agriculture in poverty reduction: An empirical perspective. Journal of Development Economics, 96, pp.239-54.

Coetzee, M., 2013. Finding the benefits: estimating the impact of the South African Child Support Grant. South African Journal of Economics, 81(3), pp.427-50.

Cousins, B., 2013. Smallholder irrigation schemes, agrarian reform and 'accumulation from above and from below' in South Africa. Journal of Agrarian Change, 13(1), pp.116-39.

D’Agostino, G., Scarlato, M. \& Napolitano, S., 2016. Do Cash Transfers Promote Food Security? The Case of the South African Child Support Grant. Munich Personal RePEC archive

Department of Social Development, 2008. Old Age Grant. [Online] Available at: http://www.dsd.gov.za/index.php?option=com_content\&task=view\&id=106 [Accessed 12 June 2015].

Dercon, S., 2009. Rural poverty: Old challenges in new contexts. The World Bank Research Observer, 24(1), pp.1-28.

Duflo, E., 2003. Grandmothers and Granddaughters: Old-Age Pensions and Intrahousehold Allocation in South Africa. The World Bank Economic Review, 17(1), pp.1-25.

Ellis, F., 1998. Household strategies and rural livelihood diversification. The Journal of Development Studies, 35(1), pp.1-38.

Evans, D.K., Hausladen, S., Kosec, K. \& Reese, N., 2014. Community-Based Conditional Cash Transfers in Tanzania: Results from a Randomized Control Trial. Washington, DC: The World Bank.

Fenyes, T. \& Meyer, N., 2003. Structure and production in South African agriculture. In L. Nieuwoudt \& J. Groenewald, eds. Agriculture in the National Economy. Pietermaritzburg: University of Natal Press. pp.21-45.

Fernald, L.C.H., Gertler, P.J. \& Neufeld, L.M., 2009. 10-year effect of Oportunidades, Mexico’s conditional cash transfer programme, on child growth, cognition, language, and behaviour: a longitudinal follow-up study. Lancet, 374, pp.1997-2005.

Fields, G., 2011. Labor market analysis for developing countries. Labour Economics, 18, pp.S16-22. 
Filipski, M.J., Taylor, J.E., Thome, K.E. \& Davis, B., 2015. Effects of treatment beyond the treated: a general equilibrium impact evaluation of Lesotho's cash grants program. Agricultural Economics, 46, pp.227-43.

Gertler, P.J., Martinez, S.W. \& Rubio-Cordina, M., 2012. Investing Cash Transfers to Raise Long-Term Living Standards. American Economic Journal: Applied Economics, 4(1), pp.164-92.

Groenewald, J. \& Nieuwoudt, L., 2003. Chapter 15: Demands on and Challenges for South African Agriculture. In L. Nieuwoudt \& J. Kirsten, eds. The challenge of change: Agriculture, land and the South African economy. Pietermaritzburg: University of Natal. pp.265-83.

Hoddinott, J., Berhane, G., Gillingan, D.O., Kumar, N. \& Taffesse, A.S., 2012. The Impact of Ethiopia’s Productive Safety Net Programme and Related Transfers on Agricultural Productivity. Journal of African Economies, 21(5), pp761-786.

Inchauste, G., Lustig, N., Maboshe, M., Purfield, C. \& Woolard, I., 2015. The Distributional Impact of Fiscal Policy in South Africa. World Bank Policy Research Working Paper. Washington DC: World Bank.

Imbens, G.W. \& Lemieux, T., 2008. Regression discontinuity designs: A guide to practise. Journal of Econometrics, 142, pp.615-35.

Jacobs, P., Ngcobo, N. \& Hart, T., 2010. Developmental social policies for the poor in South Africa: Exploring options to enhance impacts?. Human Sciences Research Council.

Klasen, S. \& Woolard, I., 2009. Surviving Unemployment Without State Support: Unemployment and Household Formation in South Africa. Journal of African Economies, 18(1), pp.1-51.

Lahiff, E. \& Cousins, B., 2005. Smallholder agriculture and land reform in South Africa. IDS Bulletin, 36(2), pp.127-31.

Lewis, F., McCosh, J. \& Nxele, Z., 2011. The influence of social welfare grants on the dependency on and valuation of wetland ecosystem services. WRC Report No. KV 279/11. Institute of Natural Resources.

Machethe, C., 2004. Agriculture and poverty in South Africa: Can agriculture reduce poverty? Paper presented at the Overcoming Underdevelopment Conference, 28-29 October 2004. Pretoria: Department of Agricultural Economic, Extension and Rural Development. 
Macours, K., Schady, N. \& Vakis, R., 2012. Cash Transfers, Behavioral Changes, and Cognitive Development in Early Childhood: Evidence from a Randomized Experiment. American Economic Journal: Applied Economics, 4(2), pp.247-73.

Neves, D. et al., 2009. The use and effectiveness of social grants in South Africa. Economic Policy Research Institute.

NPC, 2011. National Development Plan: Vision for 2030. Pretoria: National Planing Commission.

Oettle, N. et al., 1998. Agricultural services in southern Africa: Encouraging sustainable smalholder agriculture in South Africa. Glos: Environment and Development Consultancy Ltd.

Palmer, K. \& Sender, J., 2006. Prospects for On-Farm Self-Employment and Poverty Reduction: An Analysis of the South African Income and Expenditure Survey 2000. Journal of Contemporary African Studies, 24(3), pp.347-376.

Pauw, K., 2007. Agriculture and poverty: Farming for food of farming for money? Agrekon, 46(2), pp.195-218.

Posel, D., Fairburn, J.A. \& Lund, F., 2006. Labour migration and households: A reconsideration of the effects of the social pension on labour supply in South Africa, Economic Modelling, 23, pp. 836-853.

Perret, S., Anseeuw, W. \& Mathebula, F., 2005. Poverty and livelihoods in rural South Africa. Report on theme 1: Strategies for Poverty Alleviation and Food Security. Pretoria: PostGraduate School for Agriculture and Rural Development University of Pretoria.

Pienaar, L. \& Von Fintel, D., 2014. Hunger in the former apartheid homelands: Determinants of converging food security 100 years after the 1913 Land Act. Agrekon, 54(4).

Pienaar, L., 2013. Typology of smallholder farming households in South Africa's former homelands: Towards an appropriate classification system. Masters thesis. University of Stellenbosch.

Ranchhod, V., 2006. The Effect of the South African Old Age Pension on the Labour Supply of the Elderly. South African Journal of Economics, 74(4), pp.725-44.

Ranchhod, V. \& Wittenberg, M., 2016.The Social Pension and Time Allocation in Poor South African Households. In Besley, T. (ed.) Contemporary Issues in Development Economics. London: Palgrave Macmillan. 
SAGS, 2014. South African Government Services. [Online] Available at:

http://www.services.gov.za/services/content/Home/ServicesForPeople/Socialbenefits/old agegrant/en_ZA [Accessed 28 October 2014].

Schady, N. \& Rosero, J., 2008. Are cash transfers made to women spent like other sources of income? Economics Letters, 101, pp.246-48.

Sender, J., 2012. Fictions and elephants in the rondawel: a response to a brief chapter in South Africa's National Development Plan. Transformation - Critical Perspectives on Southern Africa, 78(1): pp.98-114.

Sender, J., 2016. Backward Capitalism in Rural South Africa: Prospects for Accelerating Accumulation in the Eastern Cape. Journal of Agrarian Change, 16(1), pp.3-31.

Schultz, T.P., 2004. School subsidies for the poor: evaluating the Mexican Progresa poverty program. Journal of Development Economics, 74(1), pp.199-250.

South African Social Security Agency, 2015. Statistical Report. [Online] SASSA Available at: http://www.sassa.gov.za/index.php/knowledge-centre/statisticalreports?download=367:statistical-report-3-of-2015 [Accessed 12 June 2015].

Statistics South Africa, 2008/09. Living Conditions Survey in SA. Pretoria.

Thirtle, C., van Zyl, J. \& Vink, N., 2000. South African agriculture at the crossroads: An empirical analysis of efficiency, technology and productivity. London: Macmillan Press Ltd.

Tittonell, P. et al., 2010. The diversity of rural livelihoods and their influence on soil fertility in agricultural systems of East Africa - A typology of smallholder farms. Agricultural Systems, 103, pp.83-97.

van der Berg, S., Siebrits, K. \& Lekezwa, 2010. Efficiency and equity effects of social grants in South Africa. Stellenbosch Economic Working Papers: 15/10. Stellenbosch: Department of Economics University of Stellenbosch.

Vink, N. \& Kirsten, J., 2003. Agriculture in the national economy. In L. Nieuwoudt \& J. Groenewald, eds. The challenge of change: Agriculture, land and the South African economy. Pietermaritzburg: University of Natal Press. pp.3-19. 